University of Nebraska - Lincoln

DigitalCommons@University of Nebraska - Lincoln

Faculty Publications: Department of Teaching, Department of Teaching, Learning and Teacher Learning and Teacher Education

Education

2012

\title{
The Denaturalization of Romanies in Italy: How Language and Image Work together
}

Theresa Catalano

University of Nebraska-Lincoln, tcatalano2@unl.edu

Follow this and additional works at: https://digitalcommons.unl.edu/teachlearnfacpub

Part of the Bilingual, Multilingual, and Multicultural Education Commons, Curriculum and Social Inquiry Commons, and the Social and Philosophical Foundations of Education Commons

Catalano, Theresa, "The Denaturalization of Romanies in Italy: How Language and Image Work together" (2012). Faculty Publications: Department of Teaching, Learning and Teacher Education. 129.

https://digitalcommons.unl.edu/teachlearnfacpub/129

This Article is brought to you for free and open access by the Department of Teaching, Learning and Teacher Education at DigitalCommons@University of Nebraska - Lincoln. It has been accepted for inclusion in Faculty Publications: Department of Teaching, Learning and Teacher Education by an authorized administrator of DigitalCommons@University of Nebraska - Lincoln. 


\section{THE INTERNATIONAL}

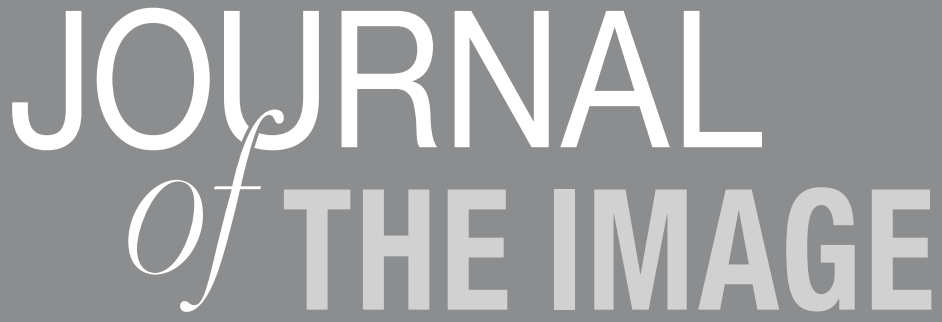

Volume 2, Issue 4

The Denaturalization of Romanies in Italy: How Language and Image Work together

Theresa Catalano 
THE INTERNATIONAL JOURNAL OF THE IMAGE http://ontheimage.com/journal/

First published in 2012 in Champaign, Illinois, USA

by Common Ground Publishing LLC

www.CommonGroundPublishing.com

ISSN: $2154-8560$

(C) 2012 (individual papers), the author(s)

(c) 2012 (selection and editorial matter) Common Ground

All rights reserved. Apart from fair dealing for the purposes of study, research, criticism or review as permitted under the applicable copyright legislation, no part of this work may be reproduced by any process without written permission from the publisher. For permissions and other inquiries, please contact

<cg-support@commongroundpublishing.com>.

THE INTERNATIONAL JOURNAL OF THE IMAGE is peer-reviewed, supported by rigorous processes of criterion-referenced article ranking and qualitative commentary, ensuring that only intellectual work of the greatest substance and highest significance is published.

Typeset in Common Ground Markup Language using CGPublisher multichannel typesetting system

http://www.commongroundpublishing.com/software/ 


\title{
The Denaturalization of Romanies in Italy: How Language and Image Work together
}

\author{
Theresa Catalano, University of Nebraska-Lincoln, USA
}

\begin{abstract}
This study attempts to reveal how the denaturalization of Romanies (a.k.a. Roma) in Italy is accomplished by Italian media through the combination of linguistic strategies and non-verbal text such as photographs and videos. Both Social Semiotics and Critical Discourse Analysis are employed in combination with Social Identity and Nationalism theories to investigate linguistic strategies and images combined in texts to create a negative context model of this group in the eyes of the Italian public. Over 10 online newspaper crime reports from the years 2004-2010 are investigated as well as Italian government websites and videos. Data analysis includes an in-depth analysis of topics, lexical choice, metaphor, and images analyzed according to Jakobson's model of the functions of language as well as other semiotic processes. Examples of images from texts are analyzed in context and their contribution to the overall message of the text is discussed in detail. Analysis reveals how images contribute to the processes of derogation and denaturalization and an underlying racist and xenophobic ideology in Italian media discourse regarding Romanies. This denaturalization of Romanies places them in the position of "scapegoat" which serves the dominant group's purpose of staying in power and provides an excellent distraction from deficiencies in government policies and the economic downturn. The goal of this study is to serve as a springboard for social and political change through the uncovering of overwhelming evidence of how dominant ideologies (which are multi-modal in nature) are reproduced in the media and the serious consequences these dominated groups face due to the media's contribution to the public's mental representation of "Them".
\end{abstract}

Keywords: Critical Discourse Analysis, Social Semiotics, Romanies, Italy, Denaturalization, Media Discourse

\section{Introduction}

IKE INSTRUMENTS IN an orchestra, words and image collaborate to produce a dominant "sound" or message. In the case of Critical Discourse Analysis, one can no longer ignore the role of non-verbal communication such as image and its contribution to the overarching message of media discourse. According to Lemke "No [written] text is an image. No text or visual representation means in all and only the same ways that text can mean. It is this essential incommensurability that enables genuine new meanings to be made from the combinations of modalities" $(2003,303)$.

Denaturalization can be defined as the act of making something appear less natural or less human which functions to "subordinate other living creatures to human beings" and "to justify denigration of certain groups of people" (Santa Ana 1999, 201). In the case of Romanies (also known as Roma and Gypsies in the U.S.) in Italy, this denaturalization helps Italians to justify human rights violations and discriminatory treatment of this group by the Italian government and individual citizens, which has placed them in the position of 
"scapegoat". This then serves the dominant group's purpose of staying in power and provides an excellent distraction from deficiencies in government policies and the economic downturn.

This paper will illustrate how image and text combine to create a negative model of Romanies and will attempt to identify the denaturalization of Romanies as it is manifested in a small sample of Italian media discourse (for a more detailed example of denaturalization in Italian media see Catalano 2011, Ch. 3). The paper begins with a brief introduction to the theoretical framework of the article, which is based in Social Semiotics and Critical Discourse Analysis. It then explains the method of analysis which includes an in-depth examination of an Italian government website photograph and accompanying text and a YouTube video. Image and text from the government website are investigated using Jakobson's model of the factors of speech events and van Leeuwen's approach to visual analysis. The YouTube video is examined using van Leeuwen's approach to visual analysis accompanied by a critical metaphorical/metonymy analysis. Results are then discussed with final suggestions made regarding the benefits of multimodal analysis to society.

\section{Social Semiotics, Critical Discourse Analysis, and the Image}

Because this study is multi-disciplinary in nature, there are many theories and approaches adopted from varying disciplines that influence its methodology, analysis, and interpretation. However, this study will review only the most relevant to this paper: (Social) Semiotics, Critical Discourse Analysis, and theories related to multi-modal analysis. One tool frequently drawn on to uncover covert meanings in texts (verbal or non-verbal) is semiotic analysis. The linguist Ferdinand de Saussure defines Semiotics as "A science that studies the life of signs within society" and claimed that Semiology shows "what constitutes signs, and what laws govern them" (Nöth 1990, 57). Semiotics can be particularly useful in multi-modal analysis and Jakobson's model of the factors of speech events and their functions is particularly useful in textual analyses such as this study. This model explains how factors such as the addresser (where the text says it originates), addressee (the audience the text is addressing), contact (the way it constructs a relationship between the addresser and addressee, that is, the physical channel and psychological connection), code (what we need to know to be able to interpret the message), context (what the message refers to) and message (the actual sign being conveyed) fulfill various functions in communication (Jakobson 1960, 353-357; Thwaites, Davies, and Mules 2002, 10, 16, 17). Other types of semiotic analyses include analysis of rhetorical devices such as metaphor and metonymy, the link between them, and the conceptualization of certain groups by society. Conceptual metaphor can be understood as mental structures that are independent of language but that can be expressed through language (Lakoff 2008, 82). Metaphorical thought is unconscious and automatic, and metaphors are comparisons that show how two things that are not alike in most ways are similar in one important way (Lakoff and Johnson, 1980). Some examples of conceptual metaphor followed by their linguistic manifestations are: ARGUMENT IS WAR: I defended my argument. LOVE IS A JOURNEY: We'll just have to go our separate ways. IDEAS ARE FOOD: I can't digest all these facts (Ibid 2003, 31). Metonymy on the other hand, directs attention to an entity through another entity related to it (Kövesces 2003, 99). Some examples of metonymy are PRODUCER FOR PRODUCT: I'm reading Shakespeare. PLACE FOR EVENT: Watergate changed our politics. OBJECT FOR USER: We need a better glove at third base (Lakoff and Johnson, 144). 
Social Semiotics expands on Saussure's founding insights by exploring the implications of the fact that the "codes" of language and communication are formed by social processes. Thus, meanings and semiotic systems are viewed as being shaped by relations of power, and that as power shifts in society, our languages and other systems of socially accepted meanings can change (Hodge and Kress 1988, 2). Social semiotics is thus the study of meaning and its social dimensions, and of the power of human processes of signification and interpretation in shaping individuals and societies. Thus, it focuses on social meaning-making practices of all types, whether visual, verbal or aural in nature (Thibault, 1991). These different systems for meaning-making or possible "channels" (e.g. speech, writing, images) are known as semiotic modes. Semiotic modes can include visual, verbal, written, gestural and musical resources for communication. They also include various "multimodal" ensembles of any of these modes (Kress and van Leeuwen 2001).

The division of labor among modes can follow various patterns. In the case of word and image, words often provide the fact and explanations while images provide interpretations and ideologically influenced angles (van Leeuwen 2008, 137). This is done by suggestion or connotation and by appealing to barely conscious, half-forgotten knowledge (Berger, 1972). According to van Leeuwen this is why visually communicated racism can be much more easily denied and more easily dismissed than verbal racism, and therefore it is even more necessary to subject images to critical analysis as well as verbal text $(2008,137)$. Barthes argued that the meaning of images and other semiotic code (such as food or dress) is always dependent on verbal text and the image-text relation can work in several ways (1967). One possibility is where the verbal text extends the meaning of the image or vice versa (referred to as relay and is where new and different meanings are added to complete the message). There is also an image-text relation where the verbal text elaborates the image or vice-versa. This is when the same/similar meaning is re-stated e.g. when a caption identifies what is found in the photograph (Kress and van Leeuwen 2006, 18). There are two kinds of elaboration. In the first type, verbal text is first, and image illustrates the text. In the second, image comes first, and the text forms a more definite and "fixed" restatement of it, referred to as anchorage. Of the two, (according to Barthes) elaboration is more dominant and found more frequently whereas relay is rarer (Ibid, 18). According to Kress and van Leeuwen (2006), what Barthes misses is that the "visual component of a text is an independently organized and structured message, connected with the verbal text, but in no way dependent on it-and similarly the other way around. Another important distinction that Kress and van Leeuwen make is that the way meaning is realized in language is different than how it is realized in image, and each medium has its own possibilities and limitations for meaning making. For example, nominalizations (such as "the confiscation of the goods" instead of "the goods were confiscated") are unique to language, while perspective is unique to image (Ibid, 19). However, "both language and visual communication express meanings belonging to and structured by cultures in the one society; the semiotic processes, not the means, are similar though, and result in a great degree of congruence between the two." (Ibid, 19). On the other hand, often different modes can be used to show social differences and in a multimodal text with images and words, the words may carry one meaning and the images another (Ibid, 20).

Another scholarly perspective useful for this article is Critical Discourse Analysis (CDA). The goal of CDA is to reveal the role of discourse in the (re)production and challenge of dominance that results in social inequality, including political, cultural, class, ethnic, racial 
and gender inequality (van Dijk 1993b, 250). van Dijk's approach to CDA will be incorporated into this paper and is based on the concept of social cognitions. Social cognitions are the socially shared representations of societal groups and relations, as well as mental processes such as interpretation, thinking and arguing, making inferences and learning that form a core element of the individual's social identity (van Dijk, 1993a). The exercise of power involves the influence of knowledge, beliefs, values, plans, attitudes, ideologies, norms and values, all part of social cognition. Therefore, control of the public mind is accomplished through linking the discourse to social cognitions. Furthermore, van Dijk links discursive units larger than the sentence to the production of prejudice. This is done by incorporating the idea of context models. Context models are mental representations that control much of discourse production and understanding such as genre, topic choice, local meanings and coherence, along with speech acts, rhetoric, and style (Wodak and Meyer 2001, 109). Context models allow us to explain what is relevant for the participants in a social situation. Groups in power affect discourse through the social representations shared by groups and these mental models. This study will attempt to incorporate the theory and methods described above with the aim of understanding how image and text work together specifically to create negative context models of Romanies in Italy.

\section{Method}

Because this paper is limited in size and scope, analysis of Romanies in Italian media will focus on a small sample of discourse taken from an Italian government website and a YouTube video widely distributed and related to topics found in the crime reports (cf Catalano 2011, for a look at Romanies in Italian crime reports). These texts contain both verbal and nonverbal elements, and highlights from each will be discussed in detail. The Italian government website was chosen for analysis in order to illustrate the institutionalization of discrimination against this group. Analysis of the Italian government website employs Jakobson's model of the functions of language along with van Leeuwen's three key factors of the photograph (distance, angle, and gaze) in order to uncover the underlying message of this multimodal communication.

The video was selected from the www. YouTube.com website under the search terms rom/ zingaro/nomadi [Romanies, Gypsies, nomads]. This particular video was chosen because of its artful use of the combination of image and text designed to denaturalize Romanies. Metaphor and metonymy is again examined for the video analysis in addition to Leeuwen's approach to how images depict people.

\section{Results}

\section{Italian Government Website}

The following photograph was found on the Italian government website http://www.governoberlusconi.it/dettaglio/209/1-italia-non-e-un-paese-razzista, under the category of campi nomadi [nomad camps]. Since the time of analysis the photo has been taken down, but the text remains, and serves to address the issue of Romanies and the Italian Government's treatment of them. This website is part of the government's response to a report filed by the Human Rights Commission condemning the Italian government's policies which include 
forced evictions, the fingerprinting of children, and abusive raids. Here below is the photo and the immediately accompanying text with a translation below:

\section{L'Italia Non è un Paese Razzista [Italy is Not a Racist Country]}

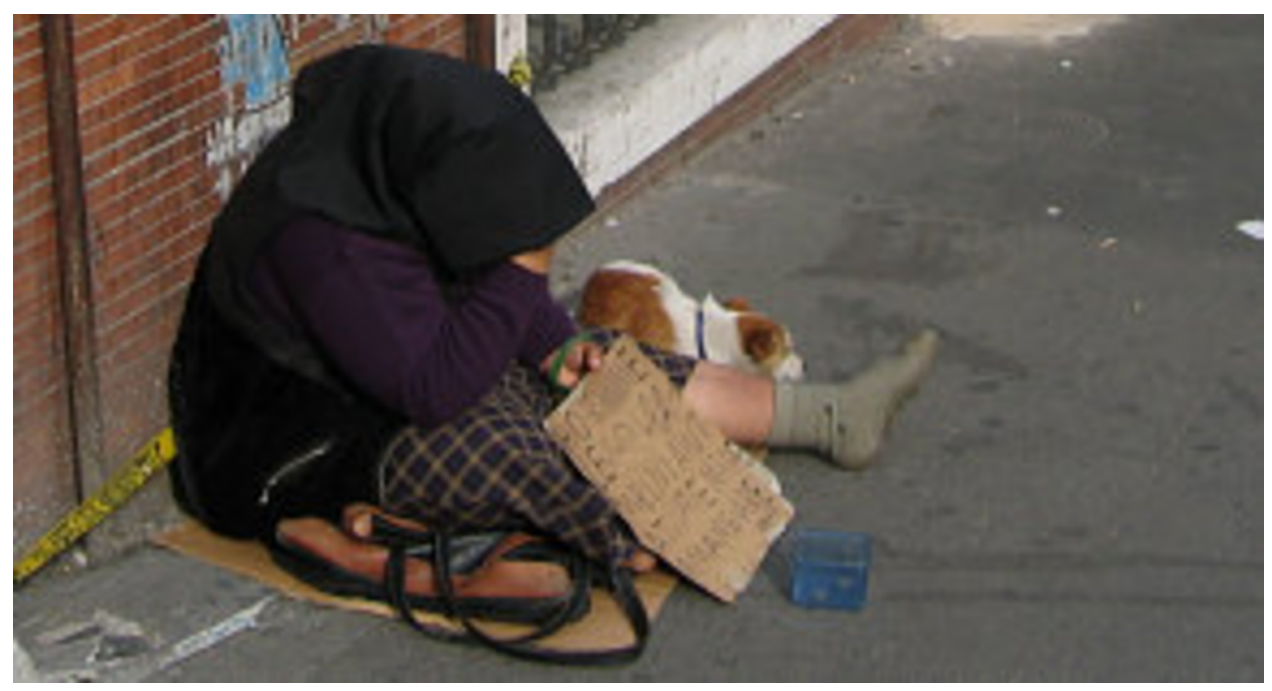

L'Italia oggi non è un Paese razzista. L'analisi dei dati statistici, dei comportamenti delle forze dell'ordine e delle politiche di integrazione attestano che il nostro Paese manifesta un'elevata capacità di accoglienza degli immigrati e che taluni episodi di violenza che si sono verificati negli ultimi tempi restano del tutto marginali e sono socialmente rifiutati. I dati in possesso al Governo, relativi agli ultimi quattro anni, dimostrano per il 2008 un 'inversione di tendenza nel numero di atti di violenza ispirati alla discriminazione e all'intolleranza. Numero di episodi che, invece, nel triennio 2005-2007 aveva registrato un progressivo aumento.

[Today's Italy is not a racist country. The analysis of statistical data of the behavior of law enforcement agencies and integration policies attest that our country manifests an elevated capacity of reception of immigrants and some episodes of violence that have been confirmed recently remain marginal and are socially rejected. Data possessed by the government from the last four years show that in 2008, there was a reversal of the number of violent acts prompted by discrimination and intolerance. Previously, during the years 2005-2007 this number had been progressively increasing.]

It is obvious that this photo does not present a positive image of Romanies in Italy, but there are several semiotic processes occurring in this photo that deserve attention as well. Although a photograph appears to be a transparent view of reality, it is not (Barthes, 1967). Just as in verbal text, non-verbal text is planned and strategic. According to van Leeuwen $(2008,141)$, there are three important variables contained in every photograph that need to be attended to: distance, angle, and gaze. Distance as seen in the photograph communicates interpersonal 
relationships and can become symbolic. In this photo, the distance is neither far nor close and is thus not noteworthy. However, the angle of the camera is. This element from which we see the person in the image "includes the vertical angle, that is whether we see the person from above, at eye level or from below, and the horizontal angle, that is, whether we see a person frontally or from the side, or perhaps from somewhere in between" (van Leeuwen 2000, 337). This angle conveys power differences. Therefore, examining the camera angle of the above photo one can clearly see a downward angle toward the subject, which denotes symbolic power over that person. This exposes a strategy of disempowerment- that is, representing people as "below us". Furthermore, the horizontal angle does not force us to face the person and therefore conveys detachment. In the case of this photo, it is clear that there is no involvement on the part of the person in the image, and she is not made to look at the viewer. That is, she is not addressing us directly and is therefore faceless. This variable is referred to as the gaze and reveals the "strategy of objectivization-representing people as objects for our scrutiny, rather than subjects addressing the viewer with their gaze and symbolically engaging with the viewer in this way" (Ibid, 339).

This photo also demonstrates the semiotic process of iconicity in the sense that the woman represents a member of the Romani community. In addition, the fact that she is supposed to represent the "typical" Rom is a metonymical process in which part stands for whole, and the woman and her actions (begging) stand for what all Romanies look like and do. Since for many Italian citizens the only known contact they have with Romanies is through begging, it does not occur to the Italian government that this photo could be offensive, but merely a representation of what the average Italian knows as "rom".

In addition, the dog lying next to the woman is the recipient of the same camera distance, angle, and gaze, and therefore creates a metaphor based on indexicality (because they are next to each other), which compares the woman with the animal. Although one might argue that the appearance of a puppy next to the woman is in fact naturalizing, from an Italian cultural perspective it is not. This is because in Italian culture dogs are still generally considered dirty and often do not live inside the home. Furthermore, the fact that the woman is not wearing shoes is very telling in Italian society where being without shoes is not conventional. All of these details in the photo work to differentiate the woman from what Italians would consider "Us".

Incorporating Jakobsen's functions of language, one can see that the addresser is the Italian government while the addressee is supposedly the Italian public. However, the true addressee of the message is the Human Rights Commissions and critics of Italy's policies. The contact is through the Internet and the code is perhaps what Italians have grown to understand is that Romanies are beggars. This is because Romanies for the most part have been physically isolated from Italian society, and often the only contact Romanies have with Italians is such as that shown in the photo. Therefore, the "code" Romanies= beggars, allows the photo to seem like an ordinary depiction of a "typical" Romani with the overall message of the photograph being something like "this is a typical Romani".

The verbal text, on the other hand utilizes what Ruth Wodak refers to as a "topos of numbers" ${ }^{\prime 1}$ which attempts to counter the accusations that the Italian government is racist by the Human Rights Commission. This use of statistical data to prove non-quantitative in-

\footnotetext{
${ }^{1}$ According to Krzyzyanowski \& Wodak (2009) topoi are parts of argumentation that connect the argument with the conclusion or claim.
} 
formation such as discrimination misses the point and according to Augoustinos and Every (2007), the denial of racism and prejudice can be treated as evidence of the existence of underlying prejudice in the speaker. Since this denial is part of official government policy in Italy, the implications of this opening line are ironic. In addition to the denial of racism in the headline and the accompanying photograph that works against this denial, several linguistic strategies are implemented in the text of this website to present the positive self /negative other representation of the Italian government as regards to the Romani people. One strategy with the function of indexicality is the use of deixis (words such as pronouns that can be used for purposes of positioning) such as "our country" to involve the reader as part of the government. Overall, this text and image are an example of Kress and van Leeuwen's idea that words may carry one meaning and images another $(2008,20)$.

\section{Romeni e Zingari Non Sono la Stessa Cosa [Romanians and Gypsies are Not the Same Thing]-YouTube Video}

This video (most likely authored by a Romanian citizen or person of Romanian origin living in Italy) serves the purpose of distinguishing between Romanians (as a nationality) and rom (Romanies) as an ethnic group. It is clear that the need for this video came out of the common conflation of the two by Italian citizens and media which could be due to the similarity between the two terms in Italian (rom vs. romeni/rumeni) or perhaps an intentional conflation designed to group these two together (especially when referring to negative actions) to make the negative context models of these groups stronger. To view the video, click on the link below:

\section{http://www.youtube.com/watch?v=VLClWkDfFFo}

As it is beyond the scope of this paper to discuss each element of this video, the analysis will focus on the interaction between text and image and how this interaction contributes to an overall message of denaturalization of Romanies and the contrasting naturalization of Romanians. This will be accomplished by focusing on the most dominant strategies of the video, which are the use of metaphor and metonymy.

The first element to examine in the interaction of text and image and the resulting metaphor/metonymy is the relationship of text and image to each other. This video is an example of elaboration, (mentioned in the beginning of this article) which is an image-text relation in which the verbal text elaborates the image or vice-versa. In the case of this video, the verbal text usually arrives first, and the image supposedly illustrates the text (except in several cases where the image comes first). For example, at the beginning of the video the emblem of Romanies and Romania is shown, and then the text appears (Emblema degli "zingari" -Emblema della Romania.) [Emblem of the "gypsies"-Emblem of Romania]. There are several things to note about the interaction between text and image in this case. First, there is a metonymical relationship between the two flags in that they are each supposed to represent a territory or nation. However, since Romanies are a people without a land or a nation (nor do they lay claim to one) the flag can only be a symbol of a people whereas in the case of the Romanian flag, it represents the nation of Romania. However, the contiguity of the images implies that both groups have territory and a nation, and are thus very different. Second, the term used to refer to Romanies is "zingari" [gypsies] which is largely considered a derogatory 
term (referring to people originating from Egypt, which they are not) and is not the preferred term of Romanies (rom in Italy). The use of this inaccurate and derogatory term (in quotation marks) immediately reveals the ideology of the authors of the video or their lack of education about this group as a whole.

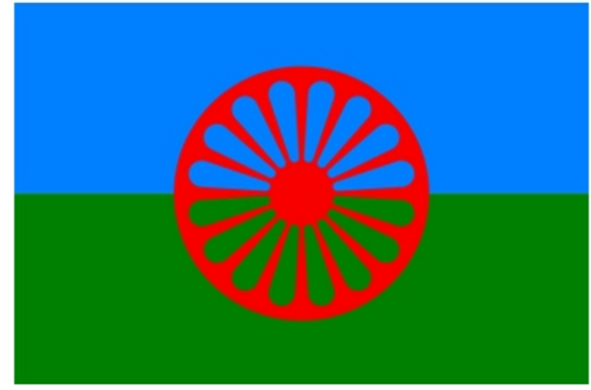

Emblema degli "zingari"

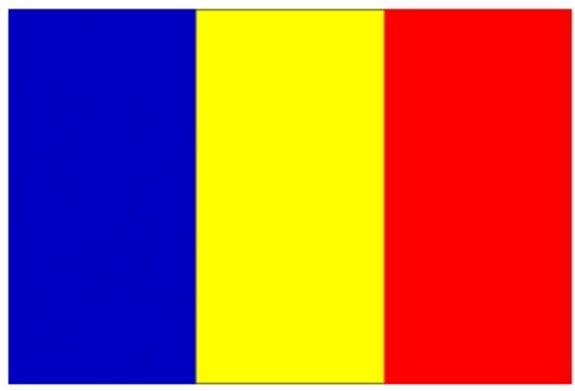

Emblema della Romania

Next in the video the emblem of Romanies is enlarged and brought to the center of the video accompanied by the text: ZINGARI... un popolo stanziatosi in Romania intorno al XV sec. ma non di origine europea [GYPSIES... a people who settled in Romania around the XV cent. but not of European origin]. This text confirms the presence of a racist ideology by highlighting the non-European origin of Romanies (not to mention it is inaccurate). ${ }^{2}$ The text is then followed by a series of images to accompany and illustrate who Romanies (called Gypsies in the video) are. This form of elaboration identifies the supposed qualities of Romanies, and illustrates the type of metonymy referred to as "defining property for category" in which the signified (the word "zingari") is substituted by what is the most "relevant" characteristic, that is, the photographs. The photographs are as follows (cf. http://www.youtube.com/watch? $\mathrm{v}=\mathrm{VLClWkDfFFo}$ ):

Man with giant cross, young men with t-shirts-"Italia" and "Suck my dick" with backs to camera, men with pitchforks, young women with long braids and skirts leaning against an expensive car, a group of men and children, two women pushing a wheelchair with a large garbage bag in it, one woman is carrying another woman on her back. They have headscarves on. A man with an "Italia" t-shirt and a giant necklace with the Virgin Mary and child, men fighting with sticks.

The photographs of Romanies serve to "Other" them and are presented as de-contextualized specimens, which are realized in different ways. According to van Leeuwen, when looking at how images depict people there are two questions one must ask; "How are people depicted?" and "How are the people depicted related to the viewer?" $(2008,138)$. With the first question, as done in the analysis of the Italian government website, the elements of distance, angle and gaze should be considered. In most of the photographs of Romanies the subjects are not addressing the camera, and the distance is almost never intimate. The camera angle is often downward (denoting symbolic power over the subjects) and the gaze is not frequently

\footnotetext{
${ }^{2}$ According to Ian Hancock, Romanies settled in Romania (then Moldovia and Wallachia) by the early 1300s and were enslaved by Romanians for over 500 years. $(2002,15-16)$
} 
toward the camera (in one photograph their backs are to the camera and another, the face is not included in the photograph, just the t-shirt and exaggerated necklace of the Virgin Mary).

In regards to the second question, there are several possibilities that a photo can include (cf. van Leeuwen, 2008, 138-147). The first is exclusion/inclusion. In this case, what is included are negative and aggressive images of Romanies (e.g. men running with sticks, men with pitchforks, women begging), while images of Romanies engaged in positive everyday situations are almost entirely excluded (such as posing for a family photo or eating dinner). Also almost entirely excluded from the images representing Romanies are children and school. Another element to include is roles, which refers to what actions the participants are involved in, and what their roles are in those actions (e.g. Agent-doers of the action, or Patient, recipients of the action). In most of the above photographs Romanies are shown as Agents in the following negative actions: protests, begging, fighting, crime, and violence against women.

In addition, the categorization of Romanies in the video is also an important element in this analysis. According to van Leeuwen, visual categorization can be biological or cultural $(2008,145)$. Examples of cultural categorization from this video are the multiple images of women with headscarves and long braids. The mere presence of these attributes is enough, and there is no need for exaggeration or caricature. They work through connotation to convey negative values associated with this group (Ibid, 145). The type of metonymy described above, of showing us the text "Zingari" in combination with the photographs that are repeated so frequently in media reports serves to strengthen synapses in the brain which "activate, regulate and even change all aspects of our understanding, and does so through the cognitive unconscious" (Lakoff 2008, 232). When language and image interact together they do not merely express identity, they can change identity. They do not just evoke memories, but they change and shape them (Ibid, 231). Primary metaphors occur when two different kinds of experiences regularly occur together and activate two different brain areas at the same time, over and over (Ibid, 94). When we constantly see images of Romanies committing violent acts and crimes (such as running with sticks and abusing women) and see the text "Gypsies", the two begin to form the metaphor GYPSIES ARE CRIMINALS and once this "neural mapping" occurs, it is very hard to un-do. Other metaphors created from this video are ROMANIES ARE BEGGARS, ROMANIES ARE DEVILS, and ROMANIES ARE WIFE-BEATERS.

After the photographs comes the map of India and Europe, with the accompanying text which serves as "proof" of their difference, and is shown down below accompanied by the translation:

Una prova dell'origine Indiana degli zingari e la diffusione di cromosoma Y tipo HM82 (presente nel 47.3\% dei Rom) rarissimo al di fuori del subcontinente indiano. [Proof of the Indian origin of gypsies and the diffusion of chromosome Y type H-M82 (present in $47.3 \%$ of Rom) extremely rare outside of the Indian subcontinent.]

A questa caratteristica genetica si aggiunge anche la particolarità dei filamenti di DNA di tipo $M$ contenuto nei mitocondri, tipico delle populazioni indiane. [We can add to this genetic characteristic the detail of the DNA filaments of type M contained in the mitochondria, typical of Indian populations.] 
Si pensa quindi che le populazioni Rom abbiano tendencialmente una discendenza comune da un gruppo originario proveniente dall'India circa quaranta generazioni fa, successivamente frazionatosi. [It is thought then that the Romani people tend to have descended from a group originating from India around forty generations ago, subsequently broken up.]

The above text emphasizes the "genetic" differences of Romanies and is an eerie reminder of Nazi-era discourse. After the maps comes the Romanian flag with the text (Romeni...Un popolo nato dall'unione dei Daci ed I romani di Traiano") [Romanians.... A people born from the union of the Dacians and the Romans of Traiano] which legitimizes the Romanian people by naming their place in history and is in contrast to the caption for the Romani flag which tells when they settled in Romania. Finally, the following images are shown to represent the Romanian people:

Beautiful blond toddler, blue eyes, close-up of face, a group of Romanian adults, together in family photo, most very light-skinned, some very beautiful women, a young Romanian soldier in uniform carrying the flag, three young men, dressed very hip, looking at the camera and gesturing with open arms, two school boys raising their hands obediently, a young family with a baby and birthday cake, three gorgeous young people, a father and two sons with the grandfather, behind them is a quaint wood cabin, two beautiful women smiling at the camera, light-haired people in traditional festival clothing, an elderly man playing the accordion, five young graduates in graduation regalia, a close-up of a long-haired blonde looking at the camera, two police officers (man and woman) in uniform, smiling, friends with arms around each other posing for the camera, a family with a baby sitting around the table drinking coffee and posing for the camera, a young fair-skinned couple looking at the camera, men in military uniforms with arms around each other posing for the camera,

The images listed above form metaphors of ROMANIANS ARE EUROPEAN/WHITE/ CAUCASIAN, ROMANIANS ARE GOOD, ROMANIANS ARE SMART, ROMANIANS ARE LAW-ABIDING CITIZENS, and ROMANIANS ARE EDUCATED to name a few. The metonymical relationships depicted (such as Romanian for blond super-model or Romanian for college graduate, police officer) work to form positive images of this group although Italian crime reports are full of negative representations of Romanians as well as Romanies. Therefore, the last part of this video can be seen as a response from the Romanian community in their struggle against oppression in Italy, and a struggle to correct the negative context models formed by Italian citizens about Romanians, unfortunately at the expense of Romanies.

\section{Conclusion}

This paper has shown through multi-layered analysis how the "Othering" of Romanies occurs daily in Italian media. Whether through government websites, YouTube videos or numerous other sources (cf Catalano 2011), image and text work to denaturalize Romanies forming metaphors such as ROMANIES ARE CRIMINALS. These metaphors help the public to conceptualize this group negatively, and result in negative consequences such as unjust laws and violent acts toward this group. Not only is the aim of this study to reveal the Italian media's subtle (and perhaps unconscious role) in the reproduction of ethnic inequality, but to take a step toward social change. It is hoped that through consciousness-raising as to how image plays an important role in the negative portrayal of this group, journalists and govern- 
ment organizations can attempt to discontinue racist discourse (as manifested through image and text) and improve conditions for Romanies in Italy.

\section{Acknowledgement}

The author would like to thank the following people/organizations: Luigi Catalano, Grace Fielder, Linda R. Waugh, the College of Education and Human Sciences and Department of Teaching, Learning and Teacher Education at the University of Nebraska-Lincoln. 


\section{References}

Augoustinos, Martha and Every, Danielle. 2007. "The Language of "Race" and Prejudice: A Discourse of Denial, Reason, and Liberal-Practical Politics." Journal of Language and Social Psychology. 26 (2): 123-141.

Barthe, Roland.1967. Elements of Semiology. London: Cape.

Berger, John. 1972. Ways of seeing. Harmondsworth, England: Penguin.

Catalano, Theresa. "Xeno-racism and discursive construction of "us" vs "them": Cosa nostra, wall street, and immigrant." PhD diss., University of Arizona, 2011. http://arizona.openrepository.com/arizona/bitstream/10150/145423/1/azu_etd_11550_sip1_m.pdf

Hancock, Ian. 2002. We are the Romani People: Ame Sam e Rromane Dzene. Hatfield: The University of Hertfordshire Press.

Hodge, Bob and Kress, Gunther. 1988. Social Semiotics. Ithaca, New York: Cornell University Press. Jakobson, Roman. 1960. "Closing Statement: Linguistics and Poetics." In A. Sebeok (Ed.) Style in Language, Cambridge, MA: MIT Press, 350-77.

Kövecses, Z. 2003. Metaphor and emotion: Language, culture and body in human feeling. Cambridge, U.K.: Cambridge University Press.

Kress, Gunther. \& van Leeuwen, Theo. 2001. Multimodal discourse: the modes and media of contemporary communication. London: Arnold.

Kress, Gunther. \& van Leeuwen, Theo. 2006. Reading images: The grammar of visual design. Second Edition. London: New York: Routledge.

Krzyzanowski, Michal. and Wodak, Ruth. 2009. The Politics of exclusion: Debating migration in Austria. New Brunswick, New Jersey: Transaction Publishers.

Lakoff, George and Johnson, Mark. 1980, second edition 2003. Metaphors We Live By. Chicago and London: The University of Chicago Press.

"L'Italia non è un paese razzista". [Italy is not a racist country]. 2008. GovernoBerlusconi.it. November 24. http://www.governoberlusconi.it/detail.php?id=209

Lakoff, George. 2008. The Political Mind: Why You Can't Understand $21^{\text {st }}$-Century Politics with an $18^{\text {th }}$-Century Brain. New York: The Penguin Group.

Lemke, Jay. 2002. "Travels in hypermodality." Visual communication. 1 (3): 299-326.

Nöth, Winfried. 1990. Handbook of Semiotics. Bloomington: Indiana University Press.

Santa Ana, Otto. (1999). “'Like an animal I was treated': anti-immigrant metaphor in US public discourse." Discourse \& Society. 10 (2): 191-224.

Thibault, Paul. 1991. Social semiotics as praxis: Text, social meaning making and Nabokov's Ada. Minneapolis, MN: University of Minnesota Press.

Thwaites, Tony. Davies, Lloyd and Mules, Warwick. 2002. Introducing cultural and media studies: a semiotic approach. Houndmills, U.K.: Palgrave.

van Dijk, Teun. 1993b. Principles of Critical Discourse Analysis. Discourse and Society.4 (2): 249-283. van Dik, Teun. 1993a. Elite Discourse and Racism. London: Sage Publications.

van Leeuwen, Theo. 2000. "Visual racism." In The Semiotics of Racism: Approaches in Critical Discourse Analysis. ed. Martin. Reisigl and Ruth. Wodak. 333-50. Vienna: Passagen Verlag.

van Leeuwen, Theo. 2008. Discourse and practice: New tools for critical discourse analysis. Oxford: Oxford University Press.

Wodak, Ruth \& Meyer, Michael. 2001. Methods of Critical Discourse Analysis. London: Sage Publications. 


\section{About the Author}

Dr. Theresa Catalano

Theresa Catalano has a PhD in Second Language Acquisition and Teaching and a Master's degree in English Language/Linguistics from the University of Arizona. Currently she is an Assistant Professor of Second Language Education/Applied Linguistics at the University of Nebraska-Lincoln. Her research focuses on the link between language, ideology and the oppression of minority groups, as well as second and foreign language education. 



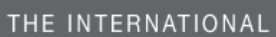 \\ JOURNAL Of THE IMAGE}

\section{Editors}

Phillip Kalantzis-Cope, The New School for Social Research, New York, USA

Tamsyn Gilbert, The New School for Social Research, New York, USA

\section{Editorial Advisory Board}

Tressa Berman, California College of the Arts, San Francisco, USA;

UTS-Sydney, Australia

Howard Besser, Tisch School of the Arts, New York University, New York City, USA

Sean Cubit, The University on Melbourne, Melbourne, Australia

Owen Evans, Edge Hill University, Ormskirk, UK

Tamsyn Gilbert, The New School for Social Research, New York City, USA

Dina lordanova, Provost, St Leonards College, University of St Andrews, Scotland

Douglas Kellner, University of California, Los Angeles, USA

Phillip Kalantzis-Cope, The New School For Social Research, New York City, USA

Gunther Kress, Institute of Education, University of London, London, UK

Emanuel Levy, Professor/Author/Critic, University of California, Los Angeles, USA

Mario Minichiello, Birmingham Institute of Art and Design, Birmingham, UK

Colin Rhodes, Sydney College of the Arts, University of Sydney, Sydney, Australia

Becky Smith, School of Theater, Film and Television, University of California, Los

Angeles, USA

Marianne Wagner-Simon, Director, Freies Museum Berlin, Germany

Please visit the Journal website at http://www.ontheimage.com for further information about the Journal or to subscribe. 


\section{The Image Community}

This knowledge community is brought together around a common shared interest in the role of The Image. The community interacts through an innovative, annual face-to-face conference, as well as year-round virtual relationships in a weblog, peer reviewed journal and book series - exploring the affordances of the new digital media.

\section{Conference}

Members of The Image Community meet at The International Conference on the Image, held annually in different locations around the world. The Conference was held at the University of California, Los Angles, USA in 2010 and at the Kursaal Congress Palace, San Sebastian, Spain in 2011. In 2012, the Conference will be held at the Higher School of Humanities and Journalism, Poznań, Poland.

Our community members and first time attendees come from all corners of the globe. The Conference is a site of critical reflection, both by leaders in the field and emerging scholars and teachers. Those unable to attend the Conference may opt for virtual participation in which community members can submit a video and/or slide presentation with voice-over, or simply submit a paper for peer review and possible publication in the Journal.

Online presentations can be viewed on YouTube.

\section{Publishing}

The Image Community enables members to publish through three mediums. First, by participating in The Image Conference, community members can enter a world of journal publication unlike the traditional academic publishing forums - a result of the responsive, non-hierarchical and constructive nature of the peer review process. The International Journal of the Image provides a framework for double-blind peer review, enabling authors to publish into an academic journal of the highest standard.

The second publication medium is through the book series The Image, publishing cutting edge books in print and electronic formats. Publication proposal and manuscript submissions are welcome.

The third major publishing medium is our news blog, constantly publishing short news updates from The Image Community, as well as major developments in the various disciplines of the image. You can also join this conversation at Facebook and Twitter or subscribe to our email Newsletter. 


\section{Common Ground Publishing Journals}

\begin{tabular}{|c|c|}
\hline $\begin{array}{l}\text { AGING } \\
\text { Aging and Society: An Interdisciplinary Journal } \\
\text { Website: http://AgingAndSociety.com/journal/ }\end{array}$ & $\begin{array}{c}\text { ARTS } \\
\text { The International Journal of the Arts in Society. } \\
\text { Website: www.Arts-Journal.com }\end{array}$ \\
\hline $\begin{array}{l}\text { BOOK } \\
\text { The International Journal of the Book } \\
\text { Website: www.Book-Journal.com }\end{array}$ & $\begin{array}{c}\text { CLIMATE CHANGE } \\
\text { The International Journal of Climate Change: } \\
\text { Impacts and Responses } \\
\text { Website: www.Climate-Journal.com }\end{array}$ \\
\hline $\begin{array}{c}\text { CONSTRUCTED ENVIRONMENT } \\
\text { The International Journal of the } \\
\text { Constructed Environment } \\
\text { Website: www.ConstructedEnvironment.com/journal }\end{array}$ & $\begin{array}{c}\text { DESIGN } \\
\text { Design Principles and Practices: } \\
\text { An International Journal } \\
\text { Website: www.Design-Journal.com }\end{array}$ \\
\hline $\begin{array}{c}\text { DIVERSITY } \\
\text { The International Journal of Diversity in } \\
\text { Organizations, Communities and Nations } \\
\text { Website: www.Diversity-Journal.com }\end{array}$ & $\begin{array}{l}\text { FOOD } \\
\text { Food Studies: An Interdisciplinary Journal } \\
\text { Website: http://Food-Studies.com/journal/ }\end{array}$ \\
\hline $\begin{array}{c}\text { GLOBAL STUDIES } \\
\text { The Global Studies Journal } \\
\text { Website: www.GlobalStudiesJournal.com }\end{array}$ & $\begin{array}{c}\text { HEALTH } \\
\text { The International Journal of Health, } \\
\text { Wellness and Society } \\
\text { Website: www.HealthandSociety.com/journal }\end{array}$ \\
\hline $\begin{array}{c}\text { HUMANITIES } \\
\text { The International Journal of the Humanities } \\
\text { Website: www.Humanities-Journal.com }\end{array}$ & $\begin{array}{c}\text { IMAGE } \\
\text { The International Journal of the Image } \\
\text { Website: www.Onthelmage.com/journal }\end{array}$ \\
\hline $\begin{array}{l}\text { LEARNING } \\
\text { The International Journal of Learning. } \\
\text { Website: www.Learning-Journal.com }\end{array}$ & $\begin{array}{c}\text { MANAGEMENT } \\
\text { The International Journal of Knowledge, } \\
\text { Culture and Change Management. } \\
\text { Website: www.Management-Journal.com }\end{array}$ \\
\hline $\begin{array}{c}\text { MUSEUM } \\
\text { The International Journal of the Inclusive Museum } \\
\text { Website: www.Museum-Journal.com }\end{array}$ & $\begin{array}{c}\text { RELIGION AND SPIRITUALITY } \\
\text { The International Journal of Religion and } \\
\text { Spirituality in Society } \\
\text { Website: www.Religion-Journal.com }\end{array}$ \\
\hline $\begin{array}{c}\text { SCIENCE IN SOCIETY } \\
\text { The International Journal of Science in Society } \\
\text { Website: www.ScienceinSocietyJournal.com }\end{array}$ & $\begin{array}{c}\text { SOCIAL SCIENCES } \\
\text { The International Journal of Interdisciplinary } \\
\text { Social Sciences } \\
\text { Website: www.SocialSciences-Journal.com }\end{array}$ \\
\hline $\begin{array}{c}\text { SPACES AND FLOWS } \\
\text { Spaces and Flows: An International Journal of } \\
\text { Urban and ExtraUrban Studies } \\
\text { Website: www.SpacesJournal.com }\end{array}$ & $\begin{array}{c}\text { SPORT AND SOCIETY } \\
\text { The International Journal of Sport and Society } \\
\text { Website: www.sportandsociety.com/journal }\end{array}$ \\
\hline $\begin{array}{c}\text { SUSTAINABILITY } \\
\text { The International Journal of Environmental, Cultural, } \\
\text { Economic and Social Sustainability } \\
\text { Website: www.Sustainability-Journal.com }\end{array}$ & $\begin{array}{c}\text { TECHNOLOGY } \\
\text { The International Journal of Technology, } \\
\text { Knowledge and Society } \\
\text { Website: www.Technology-Journal.com }\end{array}$ \\
\hline $\begin{array}{c}\text { UBIQUITOUS LEARNING } \\
\text { Ubiquitous Learning: An International Journal } \\
\text { Website: www.ubi-learn.com/journal/ }\end{array}$ & $\begin{array}{l}\text { UNIVERSITIES } \\
\text { Journal of the World Universities Forum } \\
\text { Website: www.Universities-Journal.com }\end{array}$ \\
\hline
\end{tabular}

For subscription information please contact subscriptions@commongroundpublishing.com 